\title{
Article \\ Environmental Factors Effects on Winter Wheat Competition with Herbicide-Resistant or Susceptible Silky Bentgrass (Apera spica-venti L.) in Poland
}

\author{
Agnieszka Synowiec ${ }^{1, *(\mathbb{D})}$, Beata Jop ${ }^{1, *}$, Krzysztof Domaradzki $^{2}$, Cezary Podsiadło ${ }^{3}{ }^{\circ}$, Dorota Gawęda ${ }^{4}(\mathbb{D}$, \\ Roman Wacławowicz ${ }^{5}$, Anna Wenda-Piesik ${ }^{6}{ }^{(\mathbb{O}}$, Mateusz M. Nowakowski ${ }^{6}{ }^{\circ}$, Jan Bocianowski ${ }^{7}{ }^{\circ}$, \\ Katarzyna Marcinkowska ${ }^{8}$ iD and Tadeusz Praczyk ${ }^{8}$
}

check for

updates

Citation: Synowiec, A.; Jop, B.; Domaradzki, K.; Podsiadło, C.; Gawęda, D.; Wacławowicz, R.; Wenda-Piesik, A.; Nowakowski, M.M.; Bocianowski, J.; Marcinkowska, K.; et al. Environmental Factors Effects on Winter Wheat Competition with Herbicide-Resistant or Susceptible Silky Bentgrass (Apera spica-venti L.) in Poland. Agronomy 2021, 11, 871. https://doi.org/ 10.3390/agronomy11050871

Academic Editors: Antonia María Rojano-Delgado and Ricardo Alcántara-de la Cruz

Received: 11 February 2021

Accepted: 26 April 2021

Published: 28 April 2021

Publisher's Note: MDPI stays neutral with regard to jurisdictional claims in published maps and institutional affiliations.

Copyright: (C) 2021 by the authors Licensee MDPI, Basel, Switzerland. This article is an open access article distributed under the terms and conditions of the Creative Commons Attribution (CC BY) license (https:/ / creativecommons.org/licenses/by/ $4.0 /)$.
1 Department of Agroecology and Crop Production, The University of Agriculture in Krakow, Al. Mickiewicza 21, 31120 Krakow, Poland

2 Department of Weed Science and Soil Tillage Systems, Institute of Soil Sciences and Plant Cultivation-State Research Institute, Orzechowa 61, 50540 Wrocław, Poland; k.domaradzki@iung.wroclaw.pl

3 Department of Agroengineering, The West Pomeranian University of Technology in Szczecin, Ul. Papieża Pawła VI 3, 71459 Szczecin, Poland; cezary.podsiadlo@zut.edu.pl

4 Department of Herbology and Plant Cultivation Techniques, University of Life Sciences in Lublin, Akademicka 13, 20950 Lublin, Poland; dorota.gaweda@up.lublin.pl

5 Institute of Agroecology and Plant Production, Wrocław University of Environmental and Life Sciences, Pl. Grunwaldzki 24A, 50363 Wrocław, Poland; roman.waclawowicz@upwr.edu.pl

6 Department of Agronomics, Faculty of Agriculture and Biotechnology, UTP University of Science and Technology, Al. Kaliskiego 7, 85796 Bydgoszcz, Poland; apiesik@utp.edu.pl (A.W.-P.); mateusz.m.nowakowski@gmail.com (M.M.N.)

7 Department of Mathematical and Statistical Methods, Poznań University of Life Sciences, Wojska Polskiego 28, 60637 Poznań, Poland; jan.bocianowski@up.poznan.pl

8 Institute of Plant Protection-National Research Institute, ul. Władysława Wegorka 20, 60318 Poznań, Poland; k.marcinkowska@iorpib.poznan.pl (K.M.); t.praczyk@iorpib.poznan.pl (T.P.)

* Correspondence: a.synowiec@urk.edu.pl (A.S.); beata.jop@urk.edu.pl (B.J.)

Abstract: Environmental factors, including weather and soil conditions, can affect the competitive effects of weeds on crops. This work aimed at a comparison of the competitive abilities of winter wheat toward bentgrass (Apera spica-venti (L.) P. Beauv) with single herbicide resistance, multiple herbicide resistance, or a susceptible biotype in different environmental conditions of Poland. A replacement series competition model was applied in field conditions in 2017-2018 and 2018-2019 across the country. A competitive ratio (CR) was calculated for the relative biomass of plants and grain number. A canonical variate analysis (CVA) was performed for biological parameters and a day-difference in emergence between winter wheat and bentgrass with the hydrothermal coefficient and soil texture in all of the sites in each season separately. Winter wheat emergence was correlated with the amount of precipitation after seeding, and was fastest for five days in humid conditions, and slowest up to 22 days, when the precipitation in October was low. The CVA proved that winter wheat's competitive effects toward the susceptible or herbicide-resistant biotypes of bentgrass are site-specific. During the dry season, the bentgrass biotype with multiple herbicide resistance was more competitive toward winter wheat than the susceptible one. The wheat $\mathrm{CR}<1$ with regard to biomass and both biomass and the grain number was in $64 \%$ and $50 \%$ of all the combinations with the resistant biotype. In conclusion, weather affects the competitive effects of winter wheat toward herbicide-susceptible or resistant bentgrass.

Keywords: replacement series model; competitive ratio; environmental factors

\section{Introduction}

Weeds are the most important biotic factor affecting crop production, especially in organic farming and low-input agriculture [1]. Preventing weed-induced yield losses in 
wheat has high significance for world food sustainability [2]. Environmental factors, including weather and soil conditions, are important factors influencing the yield of crops $[3,4]$ and affecting the competitive effects of weeds on crops [5,6]. Lemerle et al. [7], in the studies on the competitive effects of 12 wheat varieties against Lolium rigidum (Gaud.) performed at several sites in southeastern Australia, found that the variety $\times$ environment effects affect largely variation in crop grain yield, which is also, to a smaller extent, attributed to variety $\times$ weed $\times$ environment effects. In other studies, it was shown that wheat was more competitive toward two dicotyledonous weeds, Papaver rhoeas (L.) and Viola arvensis (Murray), during the summer drought, which restricted late weed growth and competition [8].

One of the most important annual grass weeds of winter wheat in Central, Eastern, and Northern Europe is silky bentgrass or bentgrass (Apera spica-venti (L.) P. Beauv) [9-14]. The susceptible biotypes of bentgrass pose a significant competitive threat to crops, especially winter wheat [15]. A significant decrease in wheat yield is observed at a density of bentgrass panicles $>100$ per $\mathrm{m}^{2}$ [16]. Due to a high degree of morphological and genetic variation [17], bentgrass adapts quickly to changing agricultural landscapes [18], which leads to a fast selection of herbicide-resistant biotypes [19]. A logistic regression model performed across Europe revealed that crop rotation dominated by winter crops and conventional soil tillage significantly increases the probability of resistance selection of bentgrass [20]. Presently, there are 18 cases of herbicide-resistant bentgrass in 11 different countries in Europe, with most cases from the Czech Republic, Germany, and Poland [21-23]. Biotypes of bentgrass are resistant to the inhibitors of acetolactate synthase (ALS), photosystem II, and acetyl coenzyme-A carboxylase (ACC-ase), displaying single resistance, cross-resistance, and multiple resistance patterns [21]. In Poland, the biotypes of A. spica-venti resistant to ALS inhibitors, mostly chlorsulfuron and iodosulfuron, are very common, especially in northern, western, and central parts of the country [24-26].

On the other hand, the weather and soil effects on winter wheat competitiveness against herbicide-resistant and -susceptible bentgrass are not known. The competitiveness of bentgrass increases when a set of factors occurs, i.e., lighter soil texture, cooler climate, and higher rainfall in the crop sequence comprising only autumn-sown crops and noninversion tillage [27]. A recent study showed that in a target-neighborhood competition model for wheat and bentgrass, the populations of bentgrass did not display any differences in biometrical characteristics and, as a result, competitive effects toward wheat [18]. However, more so-called "fitness benefits" of non-target site-resistant biotypes of bentgrass were found, i.e., earlier germination and flowering, than susceptible ones. The authors propose that these findings could improve the management of herbicide-resistant biotypes of bentgrass [18].

In this work, a replacement series competition model [28] was applied to study winter wheat's competitive abilities toward herbicide-resistant or -susceptible bentgrass across Poland. The method is suitable for studying the response of the yield to the proportion of competing plants. It also allows the yielding efficiency of plants in a mixture with monoculture to be determined [28,29]. However, the method also has limitations, i.e., it is not representative of most field situations where crops occur at a constant density, and the experimental outcomes may depend upon the total plant density selected and specific resource supply conditions used [30].

We hypothesize that environmental factors, i.e., weather conditions combined with soil texture, influence winter wheat's competitive abilities toward herbicide-resistant and -susceptible biotypes of bentgrass. The work aimed to compare the competitive abilities of winter wheat toward bentgrass (Apera spica-venti (L.) P. Beauv) with single herbicide resistance to ALS inhibitors, multiple herbicide resistance to ALS and ACC-ase inhibitors, or a susceptible biotype in different environmental conditions of Poland. 


\section{Materials and Methods}

In a replacement series competition model [29], two pot experiments in field conditions were set at seven different sites across Poland (Figure 1).

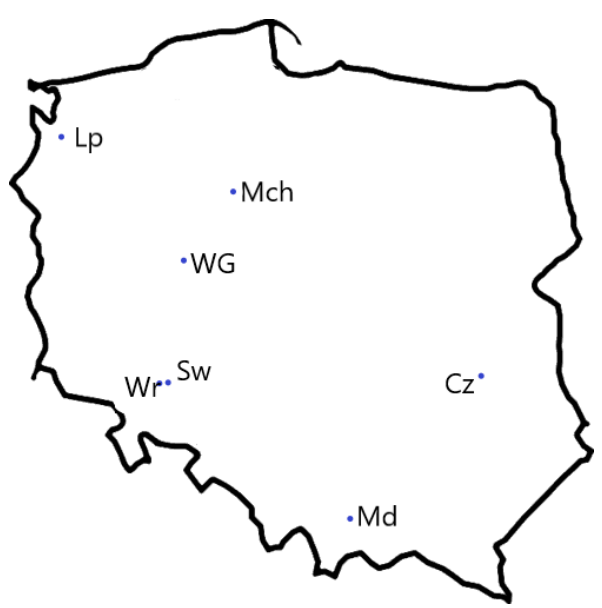

Figure 1. Distribution of the study sites. Lp-Lipnik; Mch-Mochełek; WG-Winna Góra; Cz-Czesławice; Sw-Swojczyce; Wr-Wrocław; Md-Mydlniki.

The experimental design was randomized blocks with three replications. The first experiment was performed in the 2017-2018 season in five different sites, and the second one in the 2018-2019 season in seven sites (Table 1). The scheme of pots and the distribution of plants in a pot was the same in every site. In each site, 36 pots $(22 \mathrm{~cm}$ diameter, $7 \mathrm{~L}$ vol., $0.038 \mathrm{~m}^{2}$ area) were dug into the soil at a $0.5 \mathrm{~m}$ distance, and ca. $2.5 \mathrm{~cm}$ of pot was above the soil surface. Next, they were filled up with a local arable soil from 0-30 cm layer. Before placing it in the pots, the soil was sieved through metal mesh to remove stones and other larger impurities. A soil sample was taken for detailed texture and chemical analyses (Table 1). The area between pots was laid with black foil, and the whole experiment was protected from birds with a fine plastic net.

Table 1. Sites of the experiments with their coordinates and soil characteristics.

\begin{tabular}{|c|c|c|c|c|c|c|c|c|c|c|c|}
\hline \multirow{2}{*}{ Site } & \multirow{2}{*}{ Latitude } & \multirow{2}{*}{ Longitude } & \multicolumn{3}{|c|}{ Particles (\%) } & \multirow{2}{*}{ Texture [31] } & \multirow{2}{*}{$\mathbf{N}^{1}$} & \multirow{2}{*}{$\mathbf{P}$} & \multirow{2}{*}{$\mathbf{K}$} & \multirow{2}{*}{ OM } & \multirow{2}{*}{$\mathrm{pH}$} \\
\hline & & & Sand & Silt & Clay & & & & & & \\
\hline Lipnik & $53^{\circ} 34^{\prime} \mathrm{N}$ & $14^{\circ} 95^{\prime} \mathrm{E}$ & 85.4 & 14.0 & 0.6 & Loamy sand & 0.11 & 232 & 301 & 2.2 & 6.4 \\
\hline Mochełek & $53^{\circ} 20^{\prime} \mathrm{N}$ & $17^{\circ} 86^{\prime} \mathrm{E}$ & 84.7 & 14.3 & 1.1 & Loamy sand & 0.17 & 238 & 296 & 2.6 & 6.6 \\
\hline Winna Góra- & $52^{\circ} 12^{\prime} \mathrm{N}$ & $17^{\circ} 26^{\prime} \mathrm{E}$ & 70.4 & 26.3 & 3.4 & Sandy loam & - & 137 & 162 & 1.1 & 5.5 \\
\hline Czesławice & $51^{\circ} 18^{\prime} \mathrm{N}$ & $22^{\circ} 16^{\prime} \mathrm{E}$ & 15.8 & 72.6 & 11.6 & Silt loam & 0.12 & 158 & 196 & 1.5 & 6.4 \\
\hline Swojczyce & $51^{\circ} 06^{\prime} \mathrm{N}$ & $17^{\circ} 08^{\prime} \mathrm{E}$ & 66.0 & 26.0 & 8.0 & Sandy loam & 0.51 & 128 & 125 & 1.23 & 6.5 \\
\hline Wrocław & $51^{\circ} 04^{\prime} \mathrm{N}$ & $17^{\circ} 02^{\prime} \mathrm{E}$ & 56.0 & 23.0 & 21.0 & Sandy clay loam & 1.7 & 182 & 197 & 1.19 & 6.2 \\
\hline Mydlniki & $50^{\circ} 07^{\prime} \mathrm{N}$ & $19^{\circ} 84^{\prime} \mathrm{E}$ & 39.0 & 52.0 & 9.0 & Silt loam & 0.07 & 173 & 196 & 1.14 & 6.3 \\
\hline
\end{tabular}

The characteristics of both R (herbicide-resistant) and S (herbicide-susceptible) biotypes of silky bentgrass are presented in Table 2.

The same susceptible (S) and herbicide-resistant biotypes of bentgrass were used in all of the sites; however the biotype with a single resistance (RS) was used only in the 2017-2018 season and the biotype with a multiple resistance (RM) only in the 2018-2019 season. The competitive effects of each $\mathrm{R}$ biotype of bentgrass were tested against winter wheat (WW) cv. Arkadia (breeder: HR Danko PL). 
Table 2. Characteristics of herbicide-susceptible (S) and -resistant (RS and RM) biotypes of silky bentgrass (Apera spica-venti (L.) P. Beauv) used in the pot experiments. Numbers in brackets relate to the effective dose of active ingredient causing a 50\% of reduction in plant biomass (ED50).

\begin{tabular}{ccccc}
\hline \multirow{2}{*}{ Biotype } & \multicolumn{4}{c}{ Herbicide (HRAC ${ }^{\mathbf{1}}$ Group) } \\
\cline { 2 - 5 } & $\begin{array}{c}\text { Fenoxaprop-P } \\
\text { (HRAC A) }\end{array}$ & $\begin{array}{c}\text { Pinoxaden } \\
\text { (HRAC A) }\end{array}$ & $\begin{array}{c}\text { Piroksulam } \\
\text { (HRAC B) }\end{array}$ & $\begin{array}{c}\text { Iodosulfuron } \\
\text { (HRAC B) }\end{array}$ \\
\hline $\mathrm{RS}$ & $\mathrm{S}^{2}$ & $\mathrm{~S}$ & $\mathrm{RRR}^{3}(86)$ & $\mathrm{S}$ \\
$\mathrm{RM}$ & $\mathrm{RRR}(>2650)$ & $\mathrm{RRR}(201)$ & $\mathrm{RRR}(>288)$ & $\mathrm{RRR}(>320)$ \\
$\mathrm{S}$ & $\mathrm{S}(13.2)$ & $\mathrm{S}(2.8)$ & $\mathrm{S}(<0.56)$ & $\mathrm{S}(2.41)$ \\
\hline${ }^{1}$ HRAC-Herbicide Resistance Action Committee; ${ }^{2} \mathrm{~S}$ - susceptible; $^{3}$ RRR-highly herbicide-resistant.
\end{tabular}

Grains of WW and RS or RM, and WW and S were sown in ratios: WW10:R0, WW8:R2, WW6:R4, WW4:R6, WW2:R8, WW0:R10; WW10:S0, WW8:S2, WW6:S4, WW4:S6, WW2:S8, and WW0:S10. Grains of WW, RS or RM, and S biotypes were sown on the same day, optimal for WW (Table 3). A few grains of WW were sown per spot at $2 \mathrm{~cm}$ deep and bentgrass at $0.5 \mathrm{~cm}$ deep. The spot of sowing each plant was marked.

Table 3. Dates of winter wheat sowing and harvest.

\begin{tabular}{ccccc}
\hline \multirow{2}{*}{ Site } & \multicolumn{2}{c}{ 2017-2018 Season } & \multicolumn{2}{c}{ 2018-2019 Season } \\
\cline { 2 - 5 } & Sowing Date & Harvest Date & Sowing Date & Harvest Date \\
\hline Lipnik & 20 October 2017 & 16 July 2018 & 17 October 2018 & 10 July 2019 \\
Mochełek & 9 October 2017 & 10 July 2018 & 17 October 2018 & 3 July 2019 \\
Winna Góra & - & - & 8 October 2018 & 11 July 2019 \\
Czesławice & 12 October 2017 & 13 July 2018 & 10 October 2018 & 23 July 2019 \\
Swojczyce & 18 October 2017 & 16 July 2018 & 13 October 2018 & 17 July 2019 \\
Wrocław & 27 October 2017 & 24 July 2018 & 25 October 2018 & 18 July 2019 \\
Mydlniki & - & - & 4 October 2018 & 4 July 2019 \\
\hline
\end{tabular}

In spring, the density of winter wheat (WW) and bentgrass (B) plants was thinned to one per spot. During spring, $\mathrm{N}$ fertilization was applied in $30.0 \mathrm{~g} \mathrm{NH}_{4} \mathrm{NO}_{3} \mathrm{~m}^{-2} ; 50 \%$ of the dose was applied at the beginning of vegetation, and the other dose at wheat shooting (BBCH 31-33). Wheat was harvested at a full-grain maturity (BBCH 97-99), whereas B was collected after panicles were developed but before grains were shed.

At harvest, a fresh mass of plants, both WW and B, was weighed. Plants of WW were measured with a ruler from the base of the shoots until the highest ear's tip. All grains per WW plant were counted, and their fresh mass was weighed. Based on three samples of 100 grains, the 1000-grain weight (TGW) of WW was calculated. For B, the number of grains per plant was calculated. For this, grains in two $0.01 \mathrm{~g}$ samples were counted, and then the mean number of grains was related to the weight of all grains per plant.

\subsection{Weather Conditions}

Weather data, i.e., precipitation and air temperature, were collected during the study from the nearest weather stations (Tables S1 and S2). The weather data for the months from WW sowing until harvesting, with the temperature $>0{ }^{\circ} \mathrm{C}$, namely October-December 2017 and April-July 2018, October-November 2018, and April-July 2019, were used to compute the hydrothermal coefficient (K) [32] according to the following equation:

$$
\mathrm{K}=10 \mathrm{P} / \mathrm{t}
$$

where $\mathrm{P}$ is the precipitation total and $\mathrm{t}$ is the sum of daily air temperature values.

The classification is $\mathrm{K}<1.3$ moderately dry seasons, $1.3-1.6$ optimum, and $>1.6$ classified as humid season [33]. The calculated $\mathrm{K}$ values are presented in Table 4. 
Table 4. Hydrothermal coefficient (K) calculated for the 2017-2018 and 2018-2019 seasons for the study sites.

\begin{tabular}{ccccc}
\hline Site & $\mathbf{2 0 1 7 - 2 0 1 8}$ & Classification & 2018-2019 & Classification \\
\hline Lipnik & 2.1 & Humid & 0.9 & Dry \\
Mochełek & 2.2 & Humid & 0.5 & Dry \\
Winna Góra & - & - & 0.8 & Dry \\
Czesławice & 2.6 & Humid & 1.2 & Relatively dry \\
Swojczyce & 1.5 & Optimal & 1.2 & Relatively dry \\
Wrocław & 1.2 & Relatively dry & 0.9 & Dry \\
Mydlniki & - & - & 2.6 & Humid \\
\hline
\end{tabular}

\subsection{Statistical Analysis}

The analysis was performed for the replacement series experiment [29]. The relative yield (RY) and the total relative yield (TRY) for all the measured parameters of B and WW were calculated according to the following formulas:

$$
\begin{gathered}
\mathrm{RY}_{\mathrm{WW}}=(\mathrm{p})\left(\mathrm{WW}_{\mathrm{mix}} / \mathrm{WW}_{\mathrm{mon}}\right) \\
\mathrm{RY}_{\mathrm{B}}=(\mathrm{p}-1)\left(\mathrm{B}_{\mathrm{mix}} / \mathrm{B}_{\mathrm{mon}}\right) \\
\mathrm{TRY}=\mathrm{RY}_{\mathrm{WW}}+\mathrm{RY}_{\mathrm{B}}
\end{gathered}
$$

where $R Y_{W W}$ is the relative yield of the $W W, R Y_{B}$ is the relative yield of the $B, p$ is the proportion of WW, $W_{\text {mix }}$ is a value of the WW parameter analyzed for the mixture, $W_{\text {mon }}$ is a value of the WW parameter analyzed for the monoculture, $B_{\text {mix }}$ is a value of the $B$ parameter analyzed for the mixture, $B_{\text {mon }}$ is a value of the $B$ parameter analyzed for the monoculture, and TRY is the total relative yield. The RY values for WW and B represent the mean value per single plant per pot.

Two parameters, namely fresh plant biomass and the number of grains per plant, were measured for both WW and B. That is why these parameters, calculated into RY and TRY, were presented as graphs and fitted into one of the five competition models according to [28]. The comparisons between empirical and theoretical competition models for the plants' biomass and the number of grains per plant were tested by t-test independently for each biotype, year, and site. If the RY was a straight line, it denoted no competition, a convex line showed a benefit to species, and a concave line showed a loss to species. If the TRY equaled 1 (straight line), there was a competition for the same resources between both species/biotypes. If the TRY was greater than 1 (convex), there was no competition because the demand did not exceed the resources. If TRY was less than 1 (concave), there was an antagonism that resulted in mutual loss to the species involved [34].

Moreover, the competitive ratio (CR), representing the comparative growth of WW compared to B [34], was calculated based on fresh plant biomass ( $\mathrm{CRb})$ and the number of grains (CRgn), according to the following formula:

$$
\mathrm{CR}=((1-\mathrm{p}) / \mathrm{p}) /\left(\mathrm{RY}_{\mathrm{WW}} / \mathrm{RY}_{\mathrm{B}}\right),
$$

WW was more competitive toward B if CR $>1$.

The normality of distribution of the observed traits (CRb and CRgn) was tested with Shapiro-Wilk's normality test to check whether the analysis of variance (ANOVA) met the assumption that the ANOVA model's residuals follow a normal distribution. The homogeneity of variance was tested using the Bartlett test. Multivariate normality and homogeneity of variance-covariance matrices were tested by Box's $M$ test. Next, the effects of the main factors under study (site, the proportion of plants in the mixture, and biotype) and their interactions were estimated with a linear model for the three-way ANOVA for particular traits independently for 2017-2018 and 2018-2019. The relationships between the CRb and CRgn were assessed based on Pearson's correlation coefficients and tested with the $t$-test for all of the sites separately in 2017-2018 and 2018-2019. 
Additional biometric parameters of WW in competition with RS or RM and S bentgrass in 2017-2018 and 2018-2019, separately, were also analyzed using the canonical variate analysis (CVA) [35,36]. The CVA was applied to present a multi-trait assessment of the similarity of the investigated treatments in a lower number of dimensions with the least possible loss of information. This enabled graphic illustration of the variation in the traits of all treatments under analysis. The $r$-Pearson's correlation coefficients were estimated between values of the first two canonical variates and values of original individual traits to determine the relative share of each original trait in the multivariate variation of the treatments. There were five WW parameters included in this analysis, expressed as RY, and calculated as a mean value from all the tested plant ratios: mean length and fresh biomass of plant, number of grains per plant, the grain yield per plant, and the 1000-grain weight. The number of days from sowing until WW emergence and the day difference between WW and B emergence was also included in the analysis. The environmental characteristics of the sites, namely the hydrothermal coefficient $\mathrm{K}$ and soil texture, were included as categorization variables.

The GenStat v. 18 statistical software package was used for all the analyses.

\section{Results}

The emergence of WW was noted 8-15 and 5-22 days after sowing in 2017 and 2018, respectively (Table 5). The fastest emergence of WW (5 days) was noted in Mydlniki in 2018, where the precipitation in October was highest $(52.6 \mathrm{~mm})$ among the sites, but accompanied by a cool air temperature $\left(8.2^{\circ} \mathrm{C}\right)$. On the other hand, the longest emergence time (20 and 22 days) was noted in Mochełek and Winna Góra in 2018, where the precipitation in October was low, 27.4 and $21.1 \mathrm{~mm}$, respectively (Table S1). Despite the date of sowing both WW and $B$ being the same, $B$ emerged, on average, 1-4 days later than WW in most sites (Table 5). In 2018 in Swojczyce, B emerged seven days after WW. In Mochełek and Czesławice in 2018, both WW and B emerged on the same day. The exception was Winna Góra in 2018, where B emerged seven days earlier than WW.

Table 5. Dates of winter wheat and bentgrass emergence, and the number of days from wheat sowing until emergence.

\begin{tabular}{|c|c|c|c|c|c|c|}
\hline \multirow[b]{2}{*}{ Site } & \multicolumn{3}{|c|}{2017} & \multicolumn{3}{|c|}{2018} \\
\hline & $W^{1}$ & $\begin{array}{l}\text { Days to WW } \\
\text { Emergence }\end{array}$ & $\mathbf{B}^{2}$ & WW & $\begin{array}{l}\text { Days to WW } \\
\text { Emergence }\end{array}$ & B \\
\hline $\mathrm{Lp}$ & 28 October 2017 & 8 & 30 October 2017 & 25 October 2018 & 8 & 29 October 2018 \\
\hline Mch & 24 October 2017 & 15 & 26 October 2017 & 2 November 2018 & 16 & 2 November 2018 \\
\hline WG & - & - & - & 30 October 2018 & 22 & 23 October 2018 \\
\hline $\mathrm{Cz}$ & 27 October 2017 & 15 & 28 October 2017 & 22 October 2018 & 12 & 22 October 2018 \\
\hline Sw & 26 October 2017 & 8 & 29 October 2017 & 23 October 2018 & 10 & 30 October 2018 \\
\hline $\mathrm{Wr}$ & 7 October 2017 & 11 & Nov. 10 XI 2017 & 5 November 2018 & 20 & 8 November 2018 \\
\hline Md & - & - & - & 9 October 2018 & 5 & 12 October 2018 \\
\hline
\end{tabular}

${ }^{1}$ WW-winter wheat; ${ }^{2} \mathrm{~B}$ - bentgrass.

In 2017-2018, the WW competition was tested against the biomass of bentgrass with a single resistance to piroxulam (RS) or susceptible biotype (S) (Figure 2, Table S3). The results show that in Lipnik (for S and WW), Wrocław, and Mochełek, the competitive model III occurred, pointing to two-sided negative impacts of competition on WW and RS or S bentgrass biomass. However, model I was also noted in other sites (Lipnik for RS and WW, Czesławice for S and WW, and Swojczyce for each biotype and WW), which points to both bentgrass and WW not competing in terms of biomass accumulation.

The competitive relations between WW and RS or S biotype, expressed by the number of grains per plant (Figure 3, Table S4), displayed different patterns for plant biomass. In Lipnik, the grain production of each bentgrass and WW was not affected (model IV). On the contrary, in Czesławice the RS and S biotypes and in Wrocław only the RS biotype produced a lower number of grains compared to WW (model Illb). In the other sites 
(Mochełek and Swojczyce) there was no competition for grain production between RS or S and WW (model I) (Figure 3).
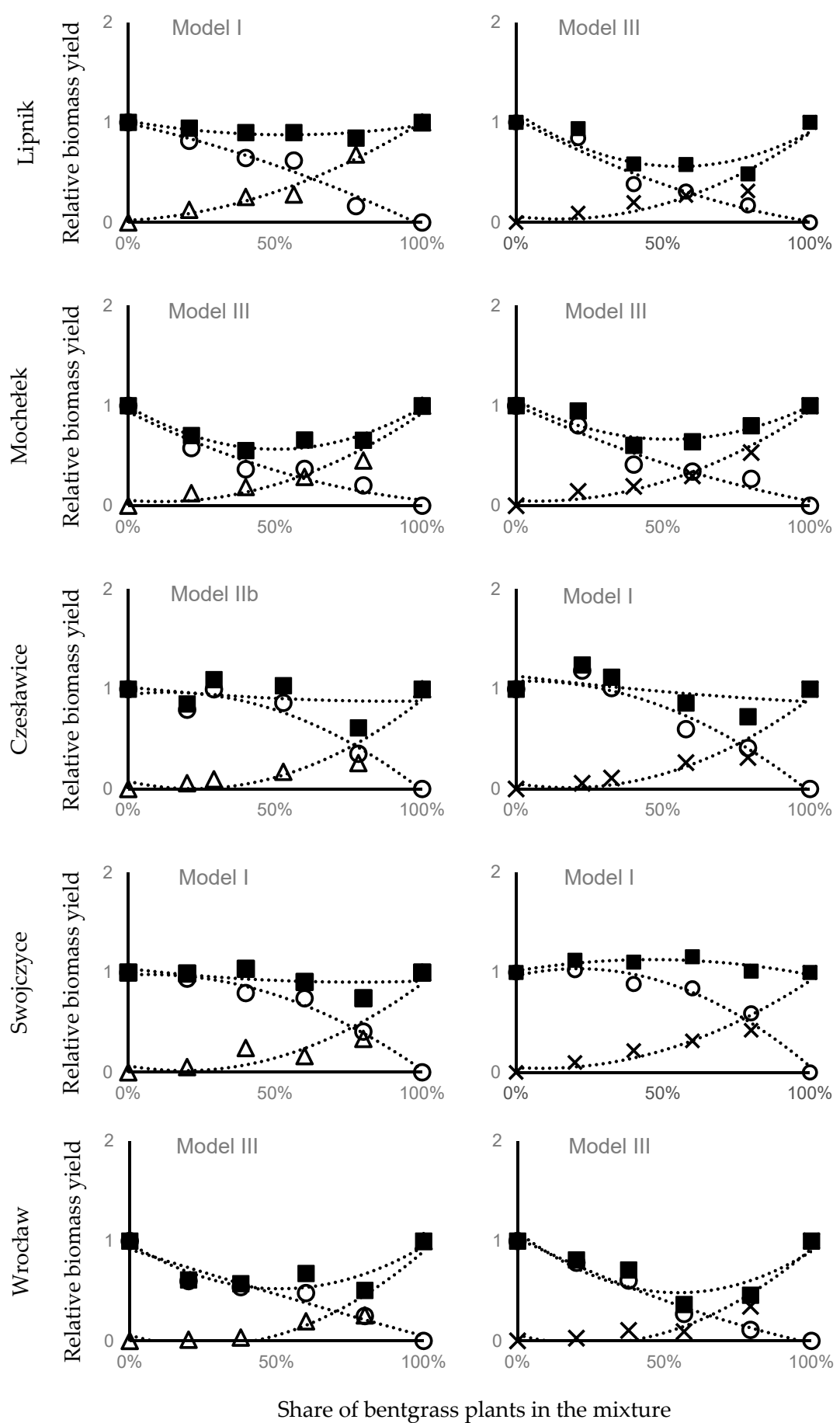

(a)

(b)

Figure 2. The substitutive competition model for the relative biomass yield of winter wheat (WW) and bentgrass in the 2017-2018 season, classified according to the t-test and $p$-values $<0.05$. (a) Competition between WW and bentgrass with a single resistance to piroxulam (RS), and (b) competition between WW and herbicide-susceptible bentgrass (S). Legend: $\bigcirc-W W ; \Delta-R S ; \times-S ; \square-R S+W W$ (a) or S + WW (b). 

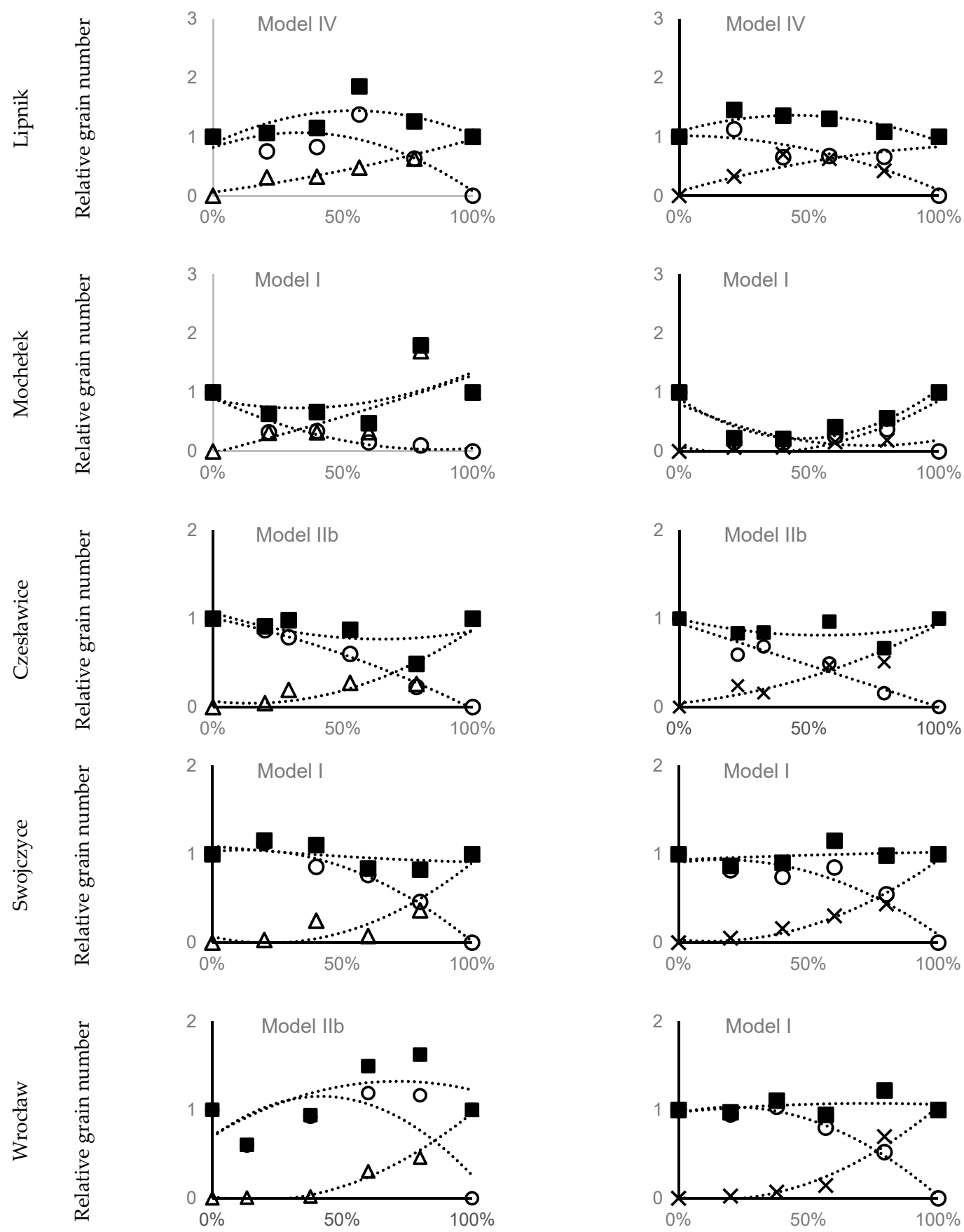

(a)

(b)

Figure 3. The substitutive competition model for the relative number of grains per plant of winter wheat (WW) and bentgrass in the 2017-2018 season, classified according to the $t$-test and $p$-values $<0.05$. (a) Competition between WW and bentgrass with a single resistance to piroxulam (RS), and (b) competition between WW and herbicide-susceptible bentgrass (S). Legend: $\bigcirc-W W ; \Delta-R S ; \times-S ; \square — R S+W W($ a) or $S+W W(\mathbf{b})$.

The competitive ratio (CR) index was measured for two parameters, i.e., biomass and grain number of $\mathrm{WW}$ and $\mathrm{B}$, in the plant ratios of $6 \mathrm{WW}: 4 \mathrm{~B}$ and $4 \mathrm{WW}: 6 \mathrm{~B}$. The site $\times$ proportion and site $\times$ proportion $\times$ biotype interactions were significant for both $C R$ indexes (Table S5).

The CRgn was significantly correlated with the CRb in the 2017-2018 season $(r=0.712$, $p<0.001$ ) (Figure 4). The analysis revealed that WW's competitive effects were higher 
in the grain number (CRgn) than in the biomass (CRb). Interestingly, the WW was less competitive only in Mochełek and toward the $S$ biotype. However, the competition with RS affected the number of grains more at both WW proportions in the mixture, as the CRgn value was below 1 for both Mch 0.4 RS and Mch 0.6 RS. In all the other sites, WW was more competitive toward both bentgrass biotypes, with CRgn $>1$. The 0.6 proportion of WW in the mixture affected the WW competitive ratio in relation mainly to RS in three sites, namely, Lipnik, Mochełek, and Swojczyce. On the other hand, in Czesławice $(\mathrm{Cz})$ the site effect prevailed over the effects of the bentgrass biotype or WW proportion in the mixture, which was displayed in the graph by a visible cluster. What is interesting is that in Czesławice the competitive ratio calculated for the relative grain number (CRgn) was very similar, in a range 1.3-1.9, regardless of the studied combinations. In the case of outliers, i.e., Sw 0.4 RS and Wr 0.6 RS, it looked more like an accidental situation than the trend.

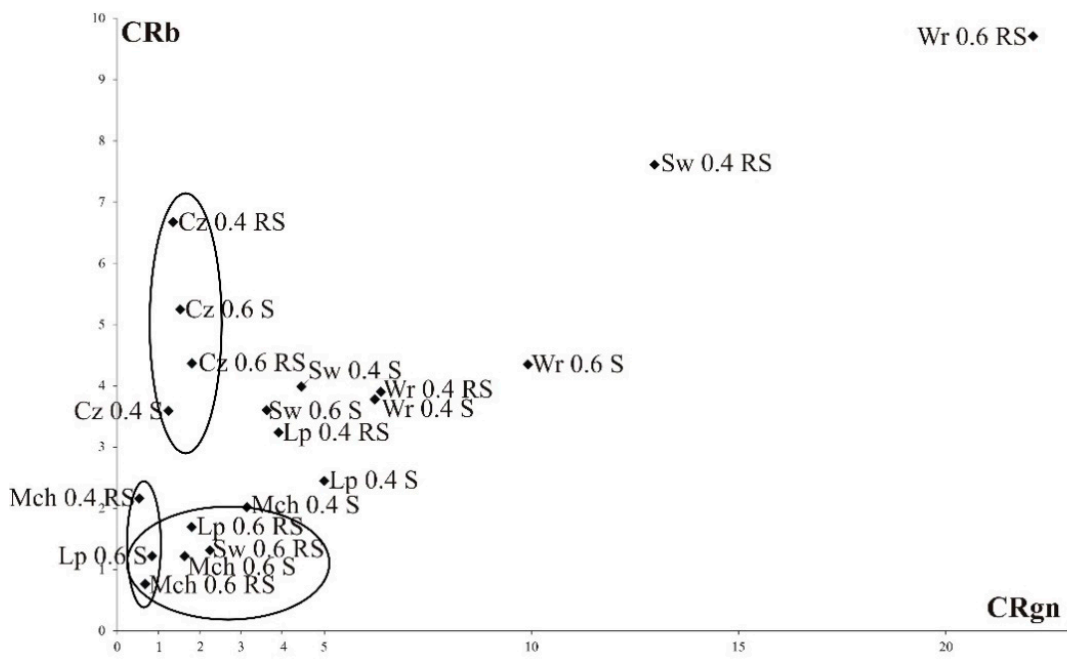

Figure 4. The distribution of sites $\times$ winter wheat proportion in the mixture $\times$ bentgrass biotypes for the competitive ratio indices calculated for the relative number of grains (CRgn) and relative biomass of plant (CRb) in 2017-2018. Legend: Lp—Lipnik, Mch-Mochełek, Cz-Czesławice, SwSwojczyce, Wr-Wrocław (sites of experiments); RS-bentgrass biotype with a single resistance; S-susceptible biotype.

The CVA was performed to find the similarities in RS's and S's competitive effects toward WW between different study sites in 2017-2018. The first canonical variable was significantly positively correlated with the number of WW grains and the days from sowing until WW emergence, and negatively with the WW grain yield. On the other hand, the second canonical variable was positively correlated with WW grain yield but negatively with the WW biomass (Table S6).

The two first canonical variables accounted for $94.25 \%$ of the total multi-variability between the individual combinations (Figure 5). The analysis revealed that WW in competition with both bentgrass biotypes displayed the best attributes in Lipnik (humid season and loamy sand soil). In Swojczyce (optimal season, sandy loam), Czesławice (humid season, silt loam), and Wrocław (relatively dry season and sandy clay loam soil), the resistant biotype RS was less competitive toward WW, compared to the S biotype in Swojczyce and Czesławice. 


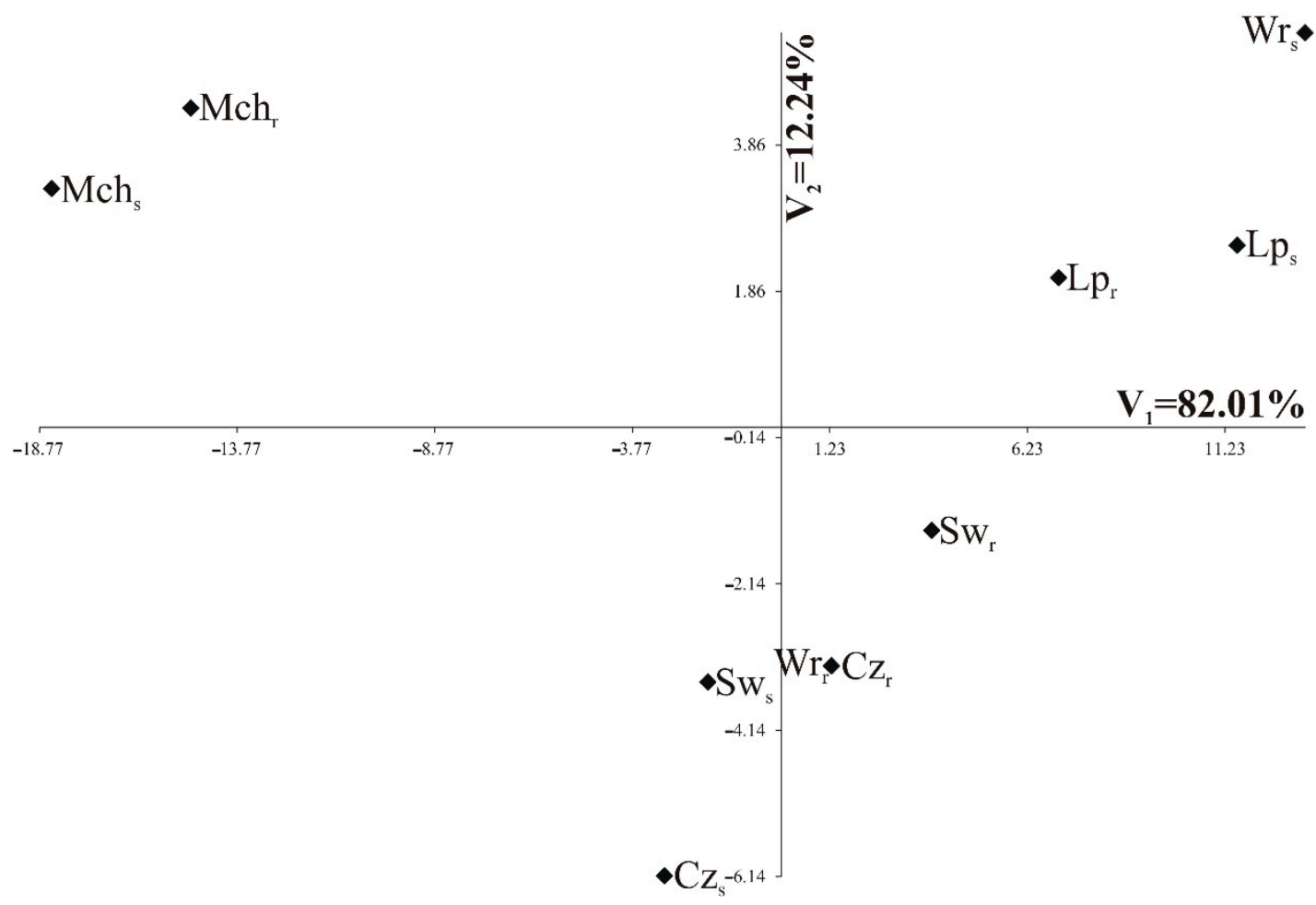

Figure 5. Distribution of five sites where the competition of winter wheat (WW) was tested against bentgrass with a single resistance to piroxulam (RS) or susceptible (S) in 2017-2018, based on five biological parameters of WW, in the space of the first two canonical variables (V1 and V2). Sites: Lp-Lipnik, Mch-Mochełek, Cz-Czesławice, Sw-Swojczyce, Wr-Wrocław. Subscript "r" denotes the competition of WW with RS and the subscript "s" with S.

In the 2018-2019 season, WW's competitive effects were tested against bentgrass with a multiple herbicide resistance (RM) and the same susceptible biotype (S) as in the 2017-2018 season. Figure 6 shows the relative yields of fresh biomass of the competing plants, and the competition model was based on the $t$-test (Table S7). The resistant biotype of bentgrass (RM) turned out to be competitive against WW in three sites out of seven, where competition model IIa was found. Interestingly, in three other sites neither the RM biotype nor WW were affected by competition (model I). The competitive efforts of the susceptible biotype $S$ were variable depending on the site.

A detailed analysis of the effect of competition between WW and BM or $\mathrm{S}$ on the grain number (Figure 7, Table S8) was different than that for plant biomass. In four out of seven sites, model I was confirmed for both BM and WW, and S and WW.

The ANOVA indicated a statistically significant influence of sites and bentgrass biotypes on the competitive ratios for the relative number of grains (CRgn) and relative biomass of plants (CRb) in 2018-2019 (Table S9). The proportion of plants in the mixture was significant for CRgn. The site $\times$ bentgrass biotype interaction was significant for both $\mathrm{CRgn}$ and $\mathrm{CRb}$. Additionally, CRgn was significantly determined by the WW proportion $\times$ bentgrass biotype interaction. 

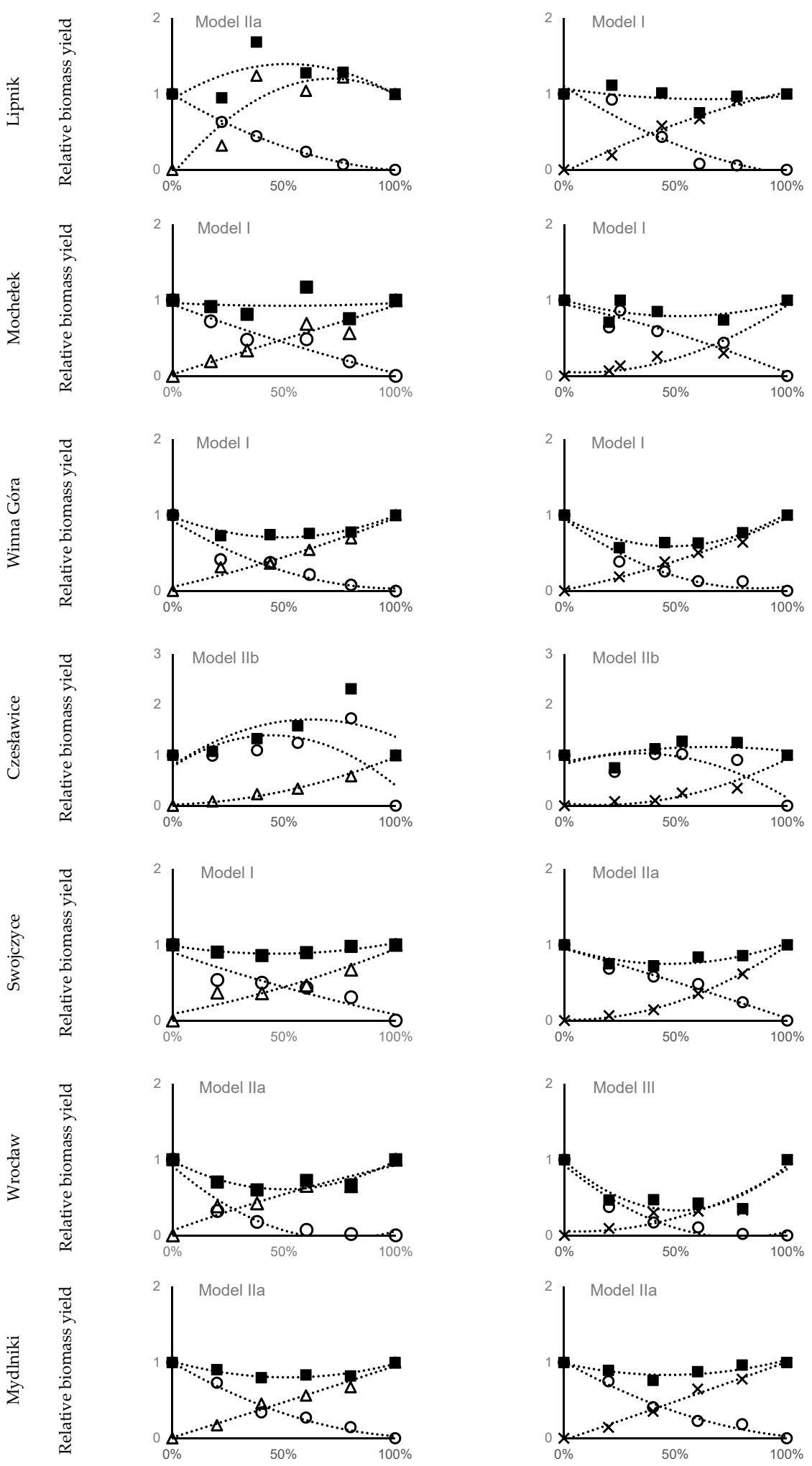

(a)

(b)

Figure 6. The substitutive competition model for the relative biomass yield of winter wheat (WW) and bentgrass in the 2018-2019 season, classified according to the $t$-test and $p$-values $<0.05$. (a) Competition between WW and bentgrass with multiple herbicide resistance (RM), and (b) competition between WW and herbicide susceptible bentgrass (S). Legend: -WW; $\Delta$-RS; $\times$ - S; $\square$-RS + WW (a) or S + WW (b). 

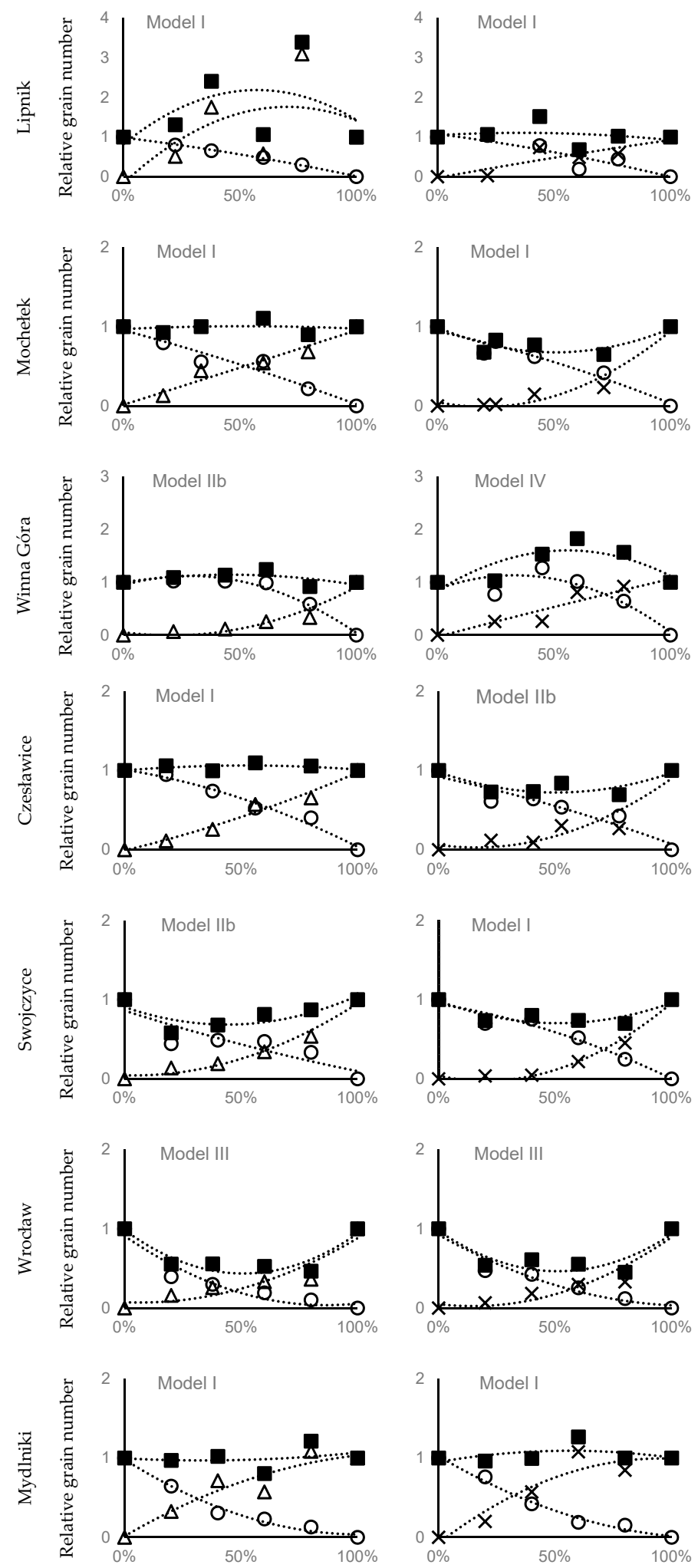

Share of bentgrass plants in the mixture

(a)

Figure 7. The substitutive competition model for the relative grain number of winter wheat (WW) and bentgrass in the 2018-2019 season, classified according to the $t$-test and $p$-values $<0.05$. (a) Competition between WW and bentgrass with multiple herbicide resistance (RM), and (b) competition between WW and herbicide susceptible bentgrass (S). Legend: $\bigcirc-W W ; \Delta-R S ; \times-S ; \square-R S+W W$ (a) or S + WW (b). 
In the 2018-2019 season, the CRgn was not correlated with the CRb $(r=0.078$, $p=0.479$ ). However, more dependencies between sites and biotypes were revealed (Figure 8). Firstly, compared to the previous season, the competitiveness of wheat, especially with regard to biomass, was lower for $64 \%$ of the combinations with RM and was in the range of 0.3-0.95. The WW displayed lower competitive effects toward the RM biotype in terms of both CRgn and CRb in Mydlniki, Wrocław, and Lipnik (50\% of all RM combinations). On the contrary, WW was visibly more competitive toward the $S$ biotype in Wrocław $(\mathrm{CRb})$ and Mochełek (CRgn) and toward the RM biotype in Czesławice (Cz 0.4 RM and Cz 0.6 RM) and Winna Góra (WG 0.4 RM and WG 0.6 RM).

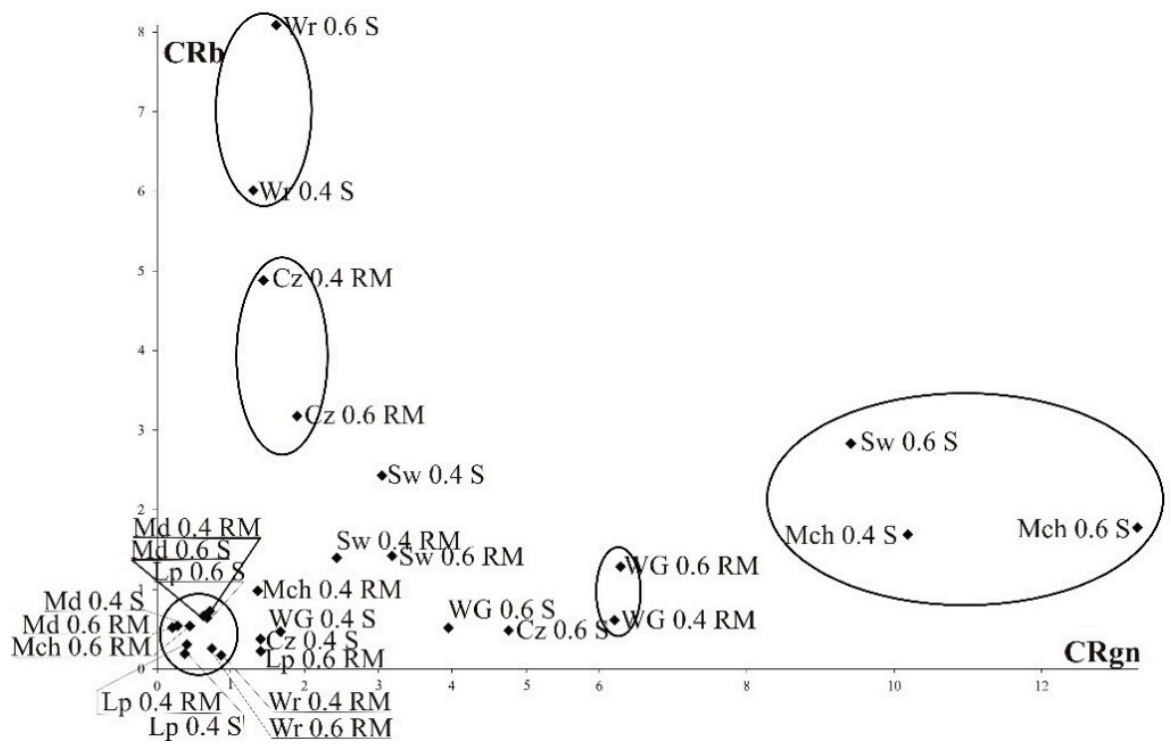

Figure 8. The distribution of sites $\times$ winter wheat proportion in the mixture $\times$ bentgrass biotypes for the competitive ratio indices calculated for the relative number of grains (CRgn) and relative biomass of plant (CRb) in 2018-2019. Legend: The sites of experiments: Lp—Lipnik, MchMochełek, Cz-Czesławice, Sw—Swojczyce, Wr-Wrocław, WG—Winna Góra, Md-Mydlniki; 0.4 and $0.6-40 \%$ and $60 \%$ proportion of winter wheat in the mixture; RM-bentgrass biotype with a multiple resistance; $\mathrm{S}$ - susceptible biotype.

The CVA was also performed in 2018-2019 for WW. The first canonical variable was positively correlated with the WW biomass and negatively with the grain yield. The second canonical variable was positively determined by the WW length, the TGW, and the day-difference between the emergence of WW and B, and negatively with WW biomass and the number of grains (Table S10).

The two canonical variables accounted for $90.04 \%$ of the total multi-variability between the individual combinations (Figure 9). In 2018-2019, WW performed best in competition with both the RM and S biotypes in Wrocław, Mydlniki, and Mochełek and the RM biotype in Swojczyce. Interestingly, those sites differed significantly in weather conditions in 2018-2019, represented here as a hydrothermal coefficient K, i.e., the vegetative season in Wrocław and Mochełek was dry, Mydlniki was humid, and Swojczyce was relatively dry. On the contrary, the poorest competitive abilities of WW, in competition with both RM and S bentgrass, were noted in Lipnik, and also in Winna Góra (dry seasons in both sites), especially in competition with the RM biotype. 


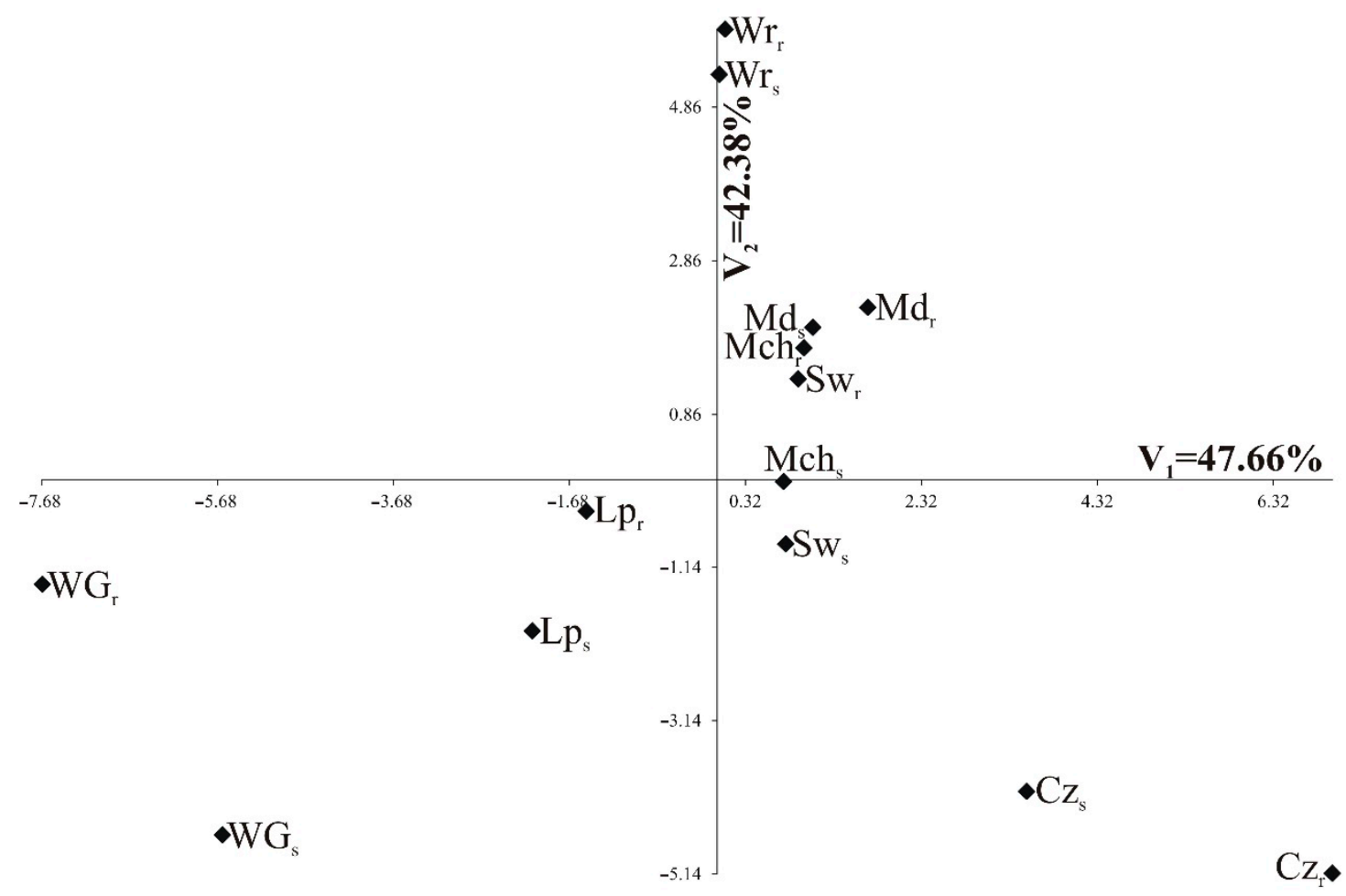

Figure 9. Distribution of seven sites where the competition of winter wheat (WW) was tested against bentgrass with multiple herbicide resistance (RM) or susceptible (S) in 2018-2019, based on five biological parameters of WW, in the space of the first two canonical variables (V1 and V2). Sites: Lp—Lipnik, Mch-Mochełek, WG-Winna Góra, Cz-Czesławice, Sw-Swojczyce, Wr-Wrocław, Md-Mydlniki. Subscript " $r$ " denotes the competition of WW with RM and the subscript "s" with S.

\section{Discussion}

The three biotypes of bentgrass of different herbicide susceptibility, i.e., one with a single resistance to ALS inhibitor, one with a multiple resistance to ALS and ACC-ase inhibitors, and the susceptible one, displayed different competitive abilities toward winter wheat $\mathrm{cv}$. Arkadia. The competition with a biotype with single resistance affected the number of winter wheat grains more. On the contrary, the biotype with multiple resistance to herbicides reduced the biomass of wheat. There are not many results regarding the competitiveness of wheat against herbicide-resistant and sensitive bentgrass biotypes, and those published did not indicate differences in competitive effects between herbicide-resistant and -susceptible biotypes toward wheat [18]. Similarly, no differences in the competitiveness of herbicide-resistant and herbicide-sensitive blackgrass (Alopecurus myosuroides Huds.) populations against wheat were demonstrated, using the target-neighborhood design model [37]. However, in another experiment, where the replacement series design was applied, competitive effects were found for wheat in association with an herbicidesusceptible Raphanus raphanistrum (L.), compared to the ALS-resistant one [38].

A holistic explanation of the problem of competition between winter wheat and herbicide-resistant/-susceptible bentgrass was found using canonical variate analysis for both seasons. In 2017-2018, wheat was more competitive toward the herbicide-susceptible bentgrass biotype in western Poland, i.e., Wrocław (southwest, relatively dry season) and Lipnik (northwest, humid season). In 2018-2019, wheat was characterized by increased competitiveness against both bentgrass biotypes, herbicide susceptible and with multiple herbicide resistance, in southern Poland in Wrocław and Mydlniki, and in northern Poland in Mochełek. In some sites this could be explained by the fact that wheat emerged fast and its seedlings were ahead of the bentgrass emergence. Many authors have emphasized that the early emergence of winter cereals, earlier also than the emergence of weeds, is 
crucial in their increased competitiveness against weeds and the resulting yield of wheat grains [7,39-41].

Based on the competitive ratio indices, we found that weather course and soil conditions in the study sites influenced the competitiveness of winter wheat against both herbicide-resistant and -sensitive bentgrass biotypes. Wheat was less competitive with the bentgrass biotypes during the dry season, especially with regard to plant biomass, compared to the season classified as humid or optimal. In other studies, [8] found a reverse situation of increased competitiveness of wheat toward two dicotyledonous weeds, namely, Papaver rhoeas (L.) and Viola arvensis (Murray), during the summer drought, which restricted late weed growth. Wheat is a crop that is especially sensitive to drought, which causes several negative biochemical, physiological, and morphological changes [42]. However, the drought resistance of wheat is cultivar dependent. Under drought conditions, some wheat cultivars produce less vegetative biomass in order to maintain the highest possible seed production $[43,44]$. In our research, the drought stress in the 2018-2019 season resulted in increased competition of wheat $\mathrm{cv}$. Arkadia with the sensitive biotype of bentgrass for seed production.

In summary, based on the replacement series design, it was shown that during the wet season, wheat $\mathrm{cv}$. Arkadia was more competitive against both bentgrass (A. spica-venti) biotypes, i.e., with single resistance and the sensitive one. During dry season, the bentgrass with multiple resistance was more competitive toward wheat in terms of plant biomass but not in terms of grain production. The competitive effects of winter wheat toward the susceptible or herbicide-resistant biotypes of bentgrass were also site-specific and weather dependent.

Supplementary Materials: The following are available online at https://www.mdpi.com/article/ 10.3390/agronomy11050871/s1, Table S1: Sum of precipitation and mean temperatures during the 2017-2018 season in the sites of study; Table S2: Sum of precipitation and mean temperatures during the 2018-2019 season in the sites of study; Table S3: The $t$-test values and $p$-values for comparison between empirical and theoretical models for biomass competition in replacement series design in 2017-2018; Table S4: The $t$-test values and $p$-values for comparison between empirical and theoretical models for grain number per plant competition in replacement series design in 2017-2018; Table S5: Mean squares from the three-way analysis of variance for the competitive ratio of winter wheat (WW) and herbicide-resistant or -susceptible bentgrass (B) calculated for the relative plant biomass (CRb) and relative grain number (CRgn) at two plant ratios 6WW:4B and 4WW:6B in the 2017-2018 season; Table S6: Results of discrimination analysis for the first and second canonical variable (cv1, cv2) for seven parameters of winter wheat (WW) in competition with herbicide-resistant or -susceptible bentgrass (B; A. spica-venti) in 2017-2018, depending on hydrothermal conditions and soil texture in the study sites; Table S7: The $t$-test values and $p$-values for comparison between empirical and theoretical models for biomass competition in replacement series design in 2018-2019; Table S8: The $t$-test values and $p$-values for comparison between empirical and theoretical models for grain number per plant competition in replacement series design in 2018-2019; Table S9: Mean squares from the three-way analysis of variance for the competitive ratio of winter wheat (WW) and herbicide-resistant or -susceptible bentgrass (B) calculated for the relative plant biomass $(\mathrm{CRb})$ and relative grain number (CRgn) at two plant ratios 6WW:4B and 4WW:6B in the 2018-2019 season; Table S10: Results of discrimination analysis for the first and second canonical variable (cv1, cv2) for seven parameters of winter wheat (WW) in competition with herbicide-resistant or -susceptible bentgrass ( $\mathrm{B} ;$ A. spica-venti) in the 2019 season, depending on hydrothermal conditions and soil texture in the study sites.

Author Contributions: Conceptualization, T.P., K.M. and A.S.; methodology, T.P., K.M. and A.S.; investigation, B.J., K.D., C.P., D.G., R.W., M.M.N. and K.M.; resources, A.S., B.J., K.D., C.P., D.G., R.W., A.W.-P., M.M.N. and K.M.; data curation, A.S. and J.B.; writing-original draft preparation, A.S. and B.J.; writing—review and editing, A.S., B.J., K.D., C.P., D.G., R.W., A.W.-P., M.M.N. and K.M.; visualization, A.S. and J.B.; supervision, T.P.; funding acquisition, T.P. All authors have read and agreed to the published version of the manuscript.

Funding: This research was funded by The National Centre for Research and Development, contract number: BIOSTRATEG 3/347445/1/NCBR/2017. 
Institutional Review Board Statement: Not applicable.

Informed Consent Statement: Not applicable.

Data Availability Statement: The data presented in this study are available on request from the corresponding author.

Conflicts of Interest: The authors declare no conflict of interest.

\section{References}

1. Scavo, A.; Mauromicale, G. Integrated Weed Management in Herbaceous Field Crops. Agronomy 2020, 10, 466. [CrossRef]

2. van der Meulen, A.; Chauhan, B.S. A review of weed management in wheat using crop competition. Crop Prot. 2017, 95, 38-44. [CrossRef]

3. Ierna, A.; Sortino, O.; Mauromicale, G. Biomass, seed and energy yield of Cynara cardunculus L. as affected by environment and season. Agronomy 2020, 10, 1548. [CrossRef]

4. Li, P.; Shi, K.; Wang, Y.; Kong, D.; Liu, T.; Jiao, J.; Hu, F. Soil quality assessment of wheat-maize cropping system with different productivities in China: Establishing a minimum data set. Soil Tillage Res. 2019, 190, 31-40. [CrossRef]

5. Van Heemst, H.D.J. The influence of weed competition on crop yield. Agric. Syst. 1985, 18, 81-93. [CrossRef]

6. Kieloch, R.; Golebiowska, H. Influence of environmental conditions and crop competition on morphological and biological diversity of Avena fatua L. and Solanum nigrum L. Acta Agrobot. 2018, 71, 1740. [CrossRef]

7. Lemerle, D.; Verbeek, B.; Orchard, B. Ranking the ability of wheat varieties to compete with Lolium rigidum. Weed Res. 2001, 41, 197-209. [CrossRef]

8. Wilson, B.J.; Wright, K.J.; Brain, P.; Clements, M.; Stephens, E. Predicting the competitive effects of weed and crop density on weed biomass, weed seed production and crop yield in wheat. Weed Res. 1995, 35, 265-278. [CrossRef]

9. Kraehmer, H.; Bell, C. Dominance of Grasses as Weeds. In Grasses: Crops, Competitors, and Ornamentals; Kraehmer, H., Ed.; Wiley: Hoboken, NJ, USA, 2019; pp. 497-502.

10. Törresen, K.S.; Salonen, J.; Fogelfors, H.; Håkansson, S.; Melander, B. Weed problems in various tillage systems in the Nordic countries. In Extended Abstracts; Nordic Association of Agricultural Scientists: Odense, Denmark, 2006; pp. 54-60.

11. Auškalnienè, O.; Kadžienè, G.; Stefanovičienè, R.; Jomantaite, B. Development of herbicides resistance in Apera spica-venti in Lithuania. Zemdirb. Agric. 2020, 107, 99-104. [CrossRef]

12. Dabkowska, T.; Łabza, T. Species from Poaceae family in cereals in selected habitats of southern Poland over the last 25 years (1981-2006). Fragm. Agron. 2010, 27, 47-59.

13. Auškalnienè, O.; Zadorozhnyi, V. Apera spica-venti (L.) P.Beauv. resistance to herbicides in Lithuania and Ukraine. Quarant. Plant Prot. 2020, 2-3, 50-52.

14. Schulz, A.; Pallurt, B.; Gerowitt, B. Effects of crop rotation and reduced nitrogen fertilisation on Apera spica-venti populations in a long-term experiment. Comm. Agric. Appl. Biol. Sci. 2011, 76, 479-483.

15. Domaradzki, K.; Rola, H.; Jezierska-Domaradzka, A. Changes in floristic composition of segetal weed community in the long-term winter wheat monoculture. Pam. Pul. 2006, 143, 59-66.

16. Rola, H. Some agrotechnical factors and competitive effect of bentgrass (Apera spica-venti) on winter wheat and winter rye. Zesz. Probl. Postep. Nauk. Rol. 1988, 349, 89-98.

17. Babineau, M.; Mahmood, K.; Mathiassen, S.K.; Kudsk, P.; Kristensen, M. De novo transcriptome assembly analysis of weed Apera spica-venti from seven tissues and growth stages. BMC Genom. 2017, 18, 128. [CrossRef]

18. Babineau, M.; Mathiassen, S.K.; Kristensen, M.; Kudsk, P. Fitness of ALS-inhibitors herbicide resistant population of loose silky bentgrass (Apera spica-venti). Front. Plant Sci. 2017, 8, 1660. [CrossRef] [PubMed]

19. Hamouzová, K.; Soukup, J.; Jursik, M.; Hamouz, P.; Venclová, V.; TůMová, P. Cross-resistance to three frequently used sulfonylurea herbicides in populations of Apera spica-venti from the Czech Republic. Weed Res. 2011, 51, 113-122. [CrossRef]

20. Massa, D.; Kaiser, Y.I.; Andújar-Sánchez, D.; Carmona-Alférez, R.; Mehrtens, J.; Gerhards, R. Development of a Geo-Referenced Database for Weed Mapping and Analysis of Agronomic Factors Affecting Herbicide Resistance in Apera spica-venti L. Beauv. (Silky Windgrass). Agronomy 2013, 3, 13-27. [CrossRef]

21. Heap, I. The International Survey of Herbicide Resistant Weeds. Thursday. Available online: www.weedscience.com (accessed on 11 February 2021).

22. Massa, D.; Gerhards, R. Investigations on herbicide resistance in European silky bent grass (Apera spica-venti) populations. J. Plant Dis. Prot. 2011, 118, 31-39. [CrossRef]

23. Hamouzová, K.; Salava, J.; Soukup, J.; Chodová, D.; Košnarová, P. Weed resistance to herbicides in the Czech Republic: History, occurrence, detection and management. In Herbicides-Mechanisms and Mode of Action; Hasaneen, M.N., Ed.; IntechOpen Ltd.: London, UK, 2011; pp. 83-102.

24. Krysiak, M.; Gawroński, S.; Adamczewski, K.; Kierzek, R. ALS gene mutations in Apera spica-venti confer broad-range resistance to herbicides. J. Plant Prot. Res. 2011, 51, 261-267. [CrossRef]

25. Stankiewicz-Kosyl, M.; Wrochna, M.; Salas, M.; Gawronski, S.W. A strategy of chemical control of Apera spica-venti L. resistant to sulfonylureas traced on the molecular level. J. Plant Prot. Res. 2017, 57, 113-119. [CrossRef] 
26. Adamczewski, K.; Kaczmarek, S.; Kierzek, R.; Matysiak, K. Significant increase of weed resistance to herbicides in Poland. J. Plant Prot. Res. 2019, 59, 139-150.

27. Melander, B.; Holst, N.; Jensen, P.K.; Hansen, E.M.; Olesen, J.E. Apera spica-venti population dynamics and impact on crop yield as affected by tillage, crop rotation, site and herbicide programmes. Weed Res. 2008, 48, 48-57. [CrossRef]

28. Radosevich, S.R. Methods to study interactions among crops and weeds. Weed Technol. 1987, 1, 190-198. [CrossRef]

29. Cousens, R. Aspects of the design and interpretation of competition (interference) experiments. Weed Technol. 1991, 5, 664-673. [CrossRef]

30. Swanton, C.J.; Nkoa, R.; Blackshaw, R.E. Experimental methods for crop-weed competition studies. Weed Sci. $2015,63,2-11$. [CrossRef]

31. WRB-World Reference for Soil Resouces. 2006. Available online: http://www.fao.org/soils-portal/soil-survey/soilclassification/world-reference-base/en/ (accessed on 28 April 2021).

32. Dacko, M.; Zając, T.; Synowiec, A.; Oleksy, A.; Klimek-Kopyra, A.; Kulig, B. New approach to determine biological and environmental factors influencing mass of a single pea (Pisum sativum L.) seed in Silesia region in Poland using a CART model. Eur. J. Agron. 2016, 74, 29-37. [CrossRef]

33. Ziernicka-Wojtaszek, A. Pluviothermal Regionalization of Poland in Light of Present-Day Climate Change. Pol. J. Environ. Stud. 2020, 29, 989-996. [CrossRef]

34. Hoffman, M.L.; Buhler, D.D. Utilizing Sorghum as a functional model of crop-weed competition. I. Establishing a competitive hierarchy. Weed Sci. 2002, 50, 466-472. [CrossRef]

35. Rencher, A.C. Interpretation of canonical discriminant functions, canonical variates, and principal components. Am. Stat. 1992, $46,217-225$.

36. Bocianowski, J.; Majchrzak, L. Analysis of effects of cover crop and tillage method combinations on the phenotypic traits of spring wheat (Triticum aestivum L.) using multivariate methods. Appl. Ecol. Environ. Res. 2019, 17, 15267-15276. [CrossRef]

37. Keshtkar, E.; Mathiassen, S.K.; Kudsk, P. No vegetative and fecundity fitness cost associated with acetyl-coenzyme a carboxylase non-target-site resistance in a black-grass (Alopecurus myosuroides Huds) population. Front. Plant Sci. 2017, 8, 2011. [CrossRef]

38. Costa, L.O.D.; Rizzardi, M.A. Competitive ability of wheat in association with biotypes of Raphanus raphanistrum L. resistant and susceptible to ALS-inhibitor herbicides. Ciênc. Agrotec. 2015, 39, 121-130. [CrossRef]

39. Fahad, S.; Hussain, S.; Chauhan, B.S.; Saud, S.; Wu, C.; Hassan, S.; Tanveer, M.; Jan, A.; Huang, J. Weed growth and crop yield loss in wheat as influenced by row spacing and weed emergence times. Crop Prot. 2015, 71, 101-108. [CrossRef]

40. Chhokar, R.S.; Sharma, R.K.; Sharma, I. Weed management strategies in wheat-A review. J. Wheat Res. $2012,4,1-21$.

41. Borger, C.P.; Hashem, A.; Gill, G.S. Comparison of growth, survivorship, seed production and shedding of eight weed species in a wheat crop in Western Australia. Weed Res. 2020, 60, 415-424. [CrossRef]

42. Razzaq, A.; Ali, Q.; Qayyum, A.; Mahmood, I.; Ahmad, M.; Rasheed, M. Physiological responses and drought resistance index of nine wheat (Triticum aestivum L.) cultivars under different moisture conditions. Pak. J. Bot. 2013, 45, 151-155.

43. Paul, K.; Pauk, J.; Deák, Z.; Sass, L.; Vass, I. Contrasting response of biomass and grain yield wheat cultivars to severe drought in Cappelle Desprez and Plainsman, V. PeerJ 2016, 4, e1708. [CrossRef]

44. Mathew, I.; Shimelis, H.; Shayanowako, A.I.T.; Laing, M.; Chaplot, V. Genome-wide association study of drought tolerance and biomass allocation in wheat. PLoS ONE 2019, 14, e225383. [CrossRef] [PubMed] 